by using a blank in which colour development due to - SH containing compounds was suppressed by addition of formaldehyde prior to addition of ferricyanide.

Fifteen pairs of determinations were carried out using embryos of sensitive and resistant strains of approximately equal age. The sulphydryl content, expressed as per cent - SH radical, of the sensitive strain varied from $120 \times 10^{-5}$ to $1,050 \times 10^{-5}$ per cent (mean $482.6 \times 10^{-5}$ per cent) while that of the resistant strain varied from $750 \times 10^{-5}$ to $1,550 \times$ $10^{-5}$ per cent (mean $983.3 \times 10^{-5}$ per cent). The mean difference between the resistant and sensitive members of the pairs was $500 \cdot 7$ in units of $10^{-5}$ per cent with a standard error of $68 \cdot 5$.

The resistant strain therefore contains slightly more than twice as much - $\mathrm{SH}$ radical as the sensitive strain.

Our thanks are due to Mr. D. C. Goch for statistical examination of the results and also to African Explosives and Chemical Industries, Ltd., for permission to publish this communication.

M. E. Thompson

A. M. JohNSTON

Research Department,

African Explosives and

Chemical Industries, Ltd., P.O. Northrand, Transvaal.

1 du Toit, Graf and Bekker, J. South Afr. Vet. Med. Assoc., 12, 50 (1941).

'Mason, J. Biol. Chem., 86, 623 (1930).

3 Mason, Proc. Staff Meetings Mayo Clinic, 4, 314 (1929).

\section{Occurrence of Strains of the Nuclear Polyhedral Virus of the Wattle Bagworm}

DuRING the past three years, experiments have been in progress ${ }^{1}$ to determine whether the wattle bagworm, Kotochalia junodi (Heyl.), could be controlled by artificially increasing the concentration of virus in plantations of black wattle, Acacia mollissima

Table 1. EFFECT OF POLYHEDROSIS JSING: (1) 'INTRODUCED' VIRUS; (a) Mortality per cent five months after treatment

\begin{tabular}{|c|c|c|c|c|}
\hline \multirow{2}{*}{} & \multicolumn{2}{|c|}{ Treated } & \multicolumn{2}{|c|}{ Untreated } \\
\cline { 2 - 5 } & Mean & Range & Mean & Range \\
\hline$(1)$ & $71 \cdot 9$ & $61 \cdot 4-7 \cdot 9 \cdot 9$ & $14 \cdot 6$ & $2 \cdot 6-18 \cdot 1$ \\
$(\mathcal{2})$ & $55 \cdot 1$ & $46 \cdot 1-60 \cdot 5$ & $15 \cdot 2$ & $9 \cdot 1-19 \cdot 9$ \\
\hline
\end{tabular}

(b) No. of survivors seven months after treatment; only live specimens collected

\begin{tabular}{|c|c|c|c|c|}
\hline & $\begin{array}{c}\text { Mean No. of } \\
\text { bagworms per } \\
\text { sample tree }\end{array}$ & Range & $\begin{array}{c}\text { Mean No. of } \\
\text { bagworms per } \\
\text { sample tree }\end{array}$ & Range \\
\hline$(1)$ & $0 \cdot 3$ & $\begin{array}{c}0-2 \\
(18 \cdot 8)^{*} \\
1-12 \\
(10 \cdot 0)^{*}\end{array}$ & 7 & $\begin{array}{c}7-45 \\
(2 \cdot 7)^{*} \\
6-9 \\
(3 \cdot 4)^{*}\end{array}$ \\
\hline
\end{tabular}
(c) No. of survivors eleven months after treatment; only mature
specimens collected

\begin{tabular}{|l|l|l|l|l|}
\hline (1) & 0 & 0 & 11 & $\begin{array}{c}3-23 \dagger \\
5-8 \dagger\end{array}$ \\
\hline
\end{tabular}

* Percentage of virus-infected specimens.

† The percentage of virus-infected imagines could not be determined since mature males emerge approximately four weeks before the females become sexually mature. At the time of collection, only empty pupal cases indicated that mature males had omerged.
Willd., and whether epizootics could be initiated by introducing the virus. In all cases, a high rate of mortality due to polyhedrosis resulted. It was noted, however, that equal concentrations of virus from different localities did not give the same kill; virus suspensions prepared from material collected in plantations remote from those treated consistently gave a higher mortality than those prepared from bagworms from the area in which they were used (Table 1).

These results not only point to a degree of resistance of the bagworm to local virus, but also strongly suggest that there are different strains within the nuclear type of virus found in $K$. junodi.

Dr. K. M. Smith of the Molteno Institute, University of Cambridge, has commented (in lit.) upon the development of resistance to virus disease in Pieris brassicae L., but this appears to be somewhat different in origin.

\section{L. J. OssowskI}

Wattle Research Institute, University of Natal, Pietermaritzburg, South Africa. Oct. 5.

1 Ossowski, L. L. J., Ann. App. Biol., 45, 81 (1957).

\section{A Shorter Microbiological Assay Method for Oxytetracycline and Chlortetracycline}

SoME organic compounds having a known effect on the growth of bacteria were used for stimulating spore germination and growth intensity of Bacillus subtilis FDA 6633, with the view of shortening the length of incubation time when assaying oxytetracycline and chlortetracycline by the cup-plate technique.

The basal medium was made up as follows: agar-agar 45 gm., peptone 7.5 gm., broth 1,500 ml. ; $p \mathbf{H}$ before sterilization $7 \cdot 0-7 \cdot 1$.

After incubation for a week in a Blake flask the $B$. subtilis spores were washed with sterile, distilled water, heated for $30 \mathrm{~min}$. at $65^{\circ} \mathrm{C}$. and centrifuged three times, washing between each centrifugation. To determine the necessary amount (per cent) of spore suspension, its light absorption was measured. The suspension is suitable if its percentage absorption is $80-90$ per cent using an orange glass parallel-sided filter with distilled water (Lange, Lichtelelektrisches Kolorimeter, Model IV). $2 \mathrm{ml}$. of this spore suspension is then diluted with a solution of selected growth factor (in this case, $98 \mathrm{ml}$. of 0.02 per cent solution of folic acid (pteroylglutamic acid)). $5.5 \mathrm{ml}$. of the diluted spore suspension is added to $100 \mathrm{ml}$. melted agar medium and thoroughly but gently stirred with a sterile glass rod. By this method only one layer, $3 \mathrm{~mm}$. thick, was poured out.

The prepared plates were stored in a refrigerator at about $+4^{\circ} \mathrm{C}$. for two days. If stored longer, the effect of the growth factor is lost. The working standards and the samples were diluted with phosphate buffer: $p \mathbf{H} 5 \cdot 0$ for oxytetracycline, and $p \mathrm{H} 4.5$ for chlortetracycline $(p \mathrm{H}, 5.0$ buffer : 90.78 gm. potassium dihydrogen phosphate ; $p \mathrm{H} 4.5$ buffer : $27.20 \mathrm{gm}$. sodium dihydrogen phosphate, both diluted to $2,000 \mathrm{ml}$. with sterile distilled water). 